\title{
HOW IMPORTANT IS INSTITUTIONAL QUALITY TO LOWER ENERGY UTILIZATION: AN ANALYSIS USING A GLOBAL PANEL OF STABLE AND UNSTABLE COUNTRIES
}

\author{
Fatemeh Dehdar* \\ University of Malaya \\ Rajah Rasiah \\ University of Malaya \\ M. Mahdi Dehdar \\ University of Tehran
}

\begin{abstract}
Efforts to lower energy intensity increased initially as a result of rising fuel prices following the first and second oil shocks, which subsequently became serious owing to mounting evidence that fossil fuels are a major cause of climate change and global warming. Energy source is a key problem associated with climate change as oil and gas, and coal constitute major components of fossil fuels. However, the extant literature remains divided on the determinants of energy intensity. Hence, using panel annual data from 84 stable and unstable countries from 1980 to 2012, this paper tested the relationship between energy intensity, and trade, FDI, urbanization, industrialization, and institutional quality. FDI in particular showed a highly significant contribution towards lowering energy-intensity, as its coefficients were negative and highly significant at $1 \%$ in all three groups of countries. However, urbanization had no impact on energy-intensity levels in all three groups of countries, while industrialization and trade exacerbated energy intensity in the global panel of countries. Whereas trade showed no relationship with energy intensity among stable and unstable countries, industrialization worsened energy intensity among stable countries. Institutional quality had a highly significant (1\%) and positive impact on reducing energy intensity in all three groups of countries.
\end{abstract}

Keywords: Energy Intensity, Institutional Quality, Generalized Method of Moments

Received: 30 October 2019

Accepted: 24 June 2020

\section{INTRODUCTION}

Energy is a fundamental need of human life and studies on it rose sharply following the first oil crisis of 1973-75, which showed the importance of energy to the economy. Its importance expanded further following the second oil shock of 1979-80. Birol and Keppler (2000) provided

\footnotetext{
* Corresponding author: Faculty of Economics and Administration, University of Malaya, 50603 Kuala Lumpur, Malaysia; HP: +60-176616035; E-mail: fdehdar86@gmail.com

We wish to thank Dr Lim Kian Ping for his suggestions
} 
evidence to show that oil intensity among the International Energy Agency (IEA) countries fell considerably following the first oil shock and by almost half after the second oil shock. Also, the energy intensity of final energy consumption of the OECD countries fell by a third between 1973 and 1998. This decline is the result of improvements of energy efficiency and decrease in energy intensity in the end-use appliances, as well as structural changes (Goldemberg \& Prado, 2011). Energy intensity can be defined as the amount of energy, measured in physical units (i.e. tones oil equivalent (TOE)), consumed per unit of GDP (Alcantara \& Duarte, 2004), which is a function of the technology level of a country, structure of the economy and fuel mix (Sun, 2002).

While volatile oil prices with sudden upsurges have initiated the massive push to lower energy intensities, concerns over global warming have since the end of 1980 s driven governments to lower the fossil fuels consumption. Since the beginning of the twentieth century global atmospheric temperatures has risen dramatically following a rise in greenhouse gas emissions (Shi, 2003). Environmental policies based on energy intensity can facilitate balancing economic growth and environmental protection targets. This is especially important for developing economies as they are facing both issues. In addition, developed economies can maintain an adequate level of consumption by application of these policies ( $\mathrm{Wu}, \mathrm{Wu}$, Cheong, \& Yu, 2018).

As countries became aware of global warming dangers at the third $\mathrm{COP}^{1}$ of the UNFCCC ${ }^{2}$, which was held in Kyoto in the year 1997, they agreed to decrease greenhouse gas emissions over 2008 to 2012 related to the 1990 levels (United Nations, 1997). Subsequently in 2015, members pledged to contribute towards capping temperature rise to 1.5 degrees Celsius over a century from 2005 levels (Rasiah, Al-Amin, Ahmed, Filho, \& Calvo, 2016). Unlike previous efforts, the COP meetings aim to mitigate climate change without compromising on economic growth. Carbon taxes and the development of renewable backstop technologies to substitute for fossil fuels and reduce the energy intensity of output, and inducements to promote sustainability transitions have been the prime channels through which these countries have targeted their energy use roadmap (Birol \& Keppler, 2000; Stern, 2007; Baležentis, Baležentis, \& Streimikiene, 2011; Adom \& Kwakwa, 2014).

Although data from British Petroleum Statistical Review of World Energy (2014) showed that world total primary energy consumption fell from $3765.1 \mathrm{MTOE}^{3}$ in 1965 to $12483.2 \mathrm{MTOE}$ in 2012, the fall in energy intensity has not been drastic enough to meet the Paris Accord schedule to mitigate climate change. Hence, several studies have since been commissioned to encourage policy recommendations. Many variables affect energy intensity: example, energy price, trade, FDI, urbanization and industrialization. Institutional quality is a variable examined on its relationship with foreign direct investment FDI (such as Daude and Stein, 2007; Busse and Hefeker, 2007: Bénassy-Quéré, Coupet, \& Mayer, 2007) but none have yet to examine a quantitative cross-country study of its link with energy intensity. Institutional quality is defined as a type of risk, which occurs as a result of unpredictable change in "the rules of the game" which businesses work under that (Butler \& Joaquin, 1998). Differences in the risk of sovereign default (Reinhart and Rogoff, 2004), human capital (Lucas, 1990), capacity to use technology (Eichengreen, 2004), and quality of institutions (Alfaro, Kalemli-Ozcan, \& Volosovych, 2008) are related to the direction of FDI flows.

\footnotetext{
${ }^{1}$ Conference of Parties

${ }^{2}$ United Nations Framework Convention for Climate Change

${ }^{3}$ million tons of oil equivalent
} 
North (1994) states that institutions have a significant role in flows of capital since economic returns from investments in emerging markets depend highly on the institutional quality. FDI brings technological innovation in firms and businesses of the host country that could result in a reduction in energy consumption (Chang, 2015). An underdeveloped institutional system would interrupt productive activities and will result in preventing the utilization of knowledge spillovers by the firms in the host country (Jude \& Levieuge, 2017). We test the influence of institutional quality as among the variables that influence energy intensity using panel of countries. The findings of this study equip policy makers with the necessary materials to devise appropriate energy policies based on the different levels of institutional quality. The remaining parts of this article is arranged as follows: the second section is the revision of the related literature on the determinants of energy intensity and institutional quality; section three discusses the measurements of variables, data sources and method of the research; section four possesses the results and analysis; and section five presents the conclusion and policy recommendations.

\section{LITERATURE REVIEW}

The key dependent variable in this paper is energy intensity. While there are several determinants of energy intensity, past works have already established their importance. What is new in this paper is the influence of institutional quality. Nevertheless, we review the existing studies on the determinants of energy intensity before assessing the role of institutional quality.

\subsection{Energy Prices}

In the 1970's, price considerations were regarded the key driver of resource substitution targeted at reducing energy intensity - labour, capital and fuel mix (Kim, 1989). Put simply an increase in energy prices will results in higher energy bills, which will cause the decrease in energy consumption. Besides, when markets become competitive, higher energy prices stimulate the generation of less energy intensive technologies, which will change the marginal productivities of the factors of production to raise the marginal productivity of energy (Adom, 2015). In this context, Edmonson (1975) included energy price effect, which led energy price to become an important determinant of energy use. Hang and Tu (2007) study of energy prices impacts on energy intensity in China revealed that raising energy prices can act as a policy tool for increasing energy use efficiency. Cornillie and Fankhauser (2004) also found that the association among energy prices and energy intensity is significant in the transition countries. Higher energy prices result in the adoption of energy efficient technologies. Komal and Abbas (2015) studied the relationship between financial development, energy consumption and economic growth in Pakistan and found that the effect of energy prices on energy consumption is negative and significant. They concluded that increasing energy prices have unfavorable effects on Pakistan's economy as the increase in cost of production has undermined competitive advantage in foreign markets. The inclusion of energy prices in the energy demand model will cause the formulation of new public policies targeted at the development of requisite technological innovations (Nasreen and Anwar, 2014). Indeed, the alternative recommended by Stern (2007) which is the main basis used by the UNFCCC is energy pricing as they call for a carbon tax to mitigate climate change and global warming. 


\subsection{Trade}

It is widely argued that energy scarcity and environmental problems could be reduced through the promotion of low-cost renewable energy resources that calls for the substitution of demand for fossil fuels with demand for non-fossil renewable energy (Stern, 2007). Hence, it is important to study the relationship between energy demand and trade, as trade is a key element of economic growth. Increasing international trade will lead to increase in economic activities and raises the energy demand (Sadorsky, 2012). In addition, trade and investment liberalization can also affect energy consumption as increasing inflows of foreign capital will stimulate demand for energy. It is important to consider the economic endowments of particular countries, and the link between economic growth and trade when attempting to investigate the effect of trade on energy demand (Cole, 2006). Trade openness increases imports of intermediate and capital goods that bring embodied technologies. Capital goods are considered to possess strong potential to stimulate productivity spillovers (Rasiah, 1995). There is also evidence to suggest that trade openness can contribute to a reduction in energy intensity of production, such as China (e.g. Hübler, 2009). Hence, Cole (2006) considered country specific factors in the relationship (both direct and indirect) between trade and energy intensity. This impact mainly depends on whether the country is importer or exporter of energy intensive products. Shen (2007) argued that trade openness improves energy efficiency, while imports of energy-intensive products rather than exports save energy consumption. Given rising concerns for global warming, it is not surprising that Sbia, Shahbaz, and Hamdi (2014) found a negative relationship between energy consumption and trade openness, owing to the adoption of energy efficient technologies. Imports of innovative technologies as a result of large-scale trade in United Arab Emirates resulted in a reduction in energy consumption (Nasreen and Anwar, 2014). Yet, Shahbaz, Nasreen, Ling, and Sbia (2014) found an inverted Ushaped association between trade openness and energy consumption in the case of high income countries and U-shaped relationship between these two variables among middle and low income countries. Sadorsky (2011) studied a group of Middle Eastern countries and concluded that energy consumption can be affected positively by raising exportation and importation in these countries. The findings of Rafiq, Salim, and Nielsen (2016) showed that trade openness significantly reduces energy intensity. Adom (2015) found that FDI and trade decrease energy intensity significantly. Other studies including Alcala and Ciccone (2004), and Waugh (2010) also confirmed that international trade is a contributing factor in decline of energy intensity through accelerating knowledge spillovers and technical upgrades which is embedded in high technology imports or by increasing competition between export-oriented firms.

\section{$2.3 \quad F D I$}

Recent works have demonstrated the importance of FDI in energy demand and energy consumption models. Stimulating FDI inflows can stimulate economic growth through raising the capital stock, demonstration effect, and technology and productivity spillover (Caves, 1974; Rasiah, 1995). However, FDI can also be a threat to the environment if it does not bring energy saving technologies and if it causes crowding out at host-sites (Rasiah, 1995; Borensztein, De Gregorio and Lee (1998); Sbia et al., 2014). Mielnik and Goldemberg (2002), who studied 20 developing countries, found an inverse relationship between FDI and energy intensity, i.e. as FDI inflows increase, energy intensity declines suggesting that foreign capital is likely to introduce best practice technologies compared to national firms in the developing countries. 
Eskeland and Harrison (2003), and Mielnik and Goldemberg (2002) showed that FDI can cause a fall or a rise in energy intensity of production and consumption. On the one hand, FDI can stimulate technology innovation in host countries that can reduce energy intensity of production and consumption (Alfaro et al., 2004, 2006; Bailliu, 2000; Chang, 2015). FDI's positive effects can be realized if technology diffusion augments the stock of knowledge via labor training, skills acquisition, new management practices and organizational arrangements, which will raise economic growth of host countries (Alguacil, Cuadros and Orts (2011); Blalock \& Gertler, 2008). Using different empirical evidence, Lee (2013), Sbia et al. (2014) and Alam, Malik, Abdullah, Hassan, Awan, Ali, Zaman and Naseem (2015) found that FDI inflows have resulted in saving energy and stimulating economic growth. FDI have also brought energy saving technologies when host country governments offer financial incentives (Hübler, 2009).

On the other hand, Zaman, Khan, Ahmad, and Rustam (2012) concluded that FDI increases electricity consumption in Pakistan. Meanwhile, Antweiler, Copeland, and Taylor (2001) argued that although FDI increases domestic production in the host country it does not change the energy intensity of that nation.

\subsection{Urbanization}

There is also evidence to suggest that urbanization is a determinant of energy demand. Social and economic modernization leads to urbanization as the transition in specialization from agriculture to industry and subsequently to services increases urbanization (Poumanyvong and Kaneko, 2010). Urbanization is important as concentrations of people participating in economic activities tend to raise energy consumption (Jones, 1991; Solarin \& Shahbaz, 2013). Mishra, Smyth and Sharma (2009) argued that urbanization provides easier access to electricity than those households living in rural areas.

Data shows that global urban population rose from 39\% to 52\% from 2012 to 1980 (WorldBank, 2016). In addition urban areas activities leaded to around $67 \%$ of the total global energy consumption and emission of 70\% of greenhouse gases (Chen \& Chen, 2015). Jones' (1991) work on the relationship between energy intensity and urbanization confirms the effects of urbanization on energy intensity, though agglomerations of population tend to raise economic activity (see also Pariakh and Shukla, 1995; Sadorsky, 2013). Also, urbanization offers the opportunity to increase energy efficiency through economies of scale (Sadorsky, 2013), such as through more efficient use of public infrastructure, including in lowering energy demand and emissions of greenhouse gases (Chen, Jia, \& Lau, 2008; Liddle, 2004). However, the evidence is mixed. For example, Adom and Kwakwa (2014) stated that there is a positive and significant relationship between urbanization and energy intensity in Ghana. Shahbaz and Lean (2012) found that increasing urbanization can lead to a raise in energy consumption in Tunisia. Poumanyvong and Kaneko (2010) went further to argue that the relationship between urbanization and energy consumption and emissions, depends on the development of the countries whose results indicate that urbanization lowers energy consumption in low income countries, while raises energy consumption in the middle and high income countries. 


\subsection{Industrialization}

Especially since the first (1973-75) and second (1979-80) oil crises, structural change, especially the shift towards industrialization, was identified as a determinant of energy consumption (Ang and Zhang, 2000). For instance, industries such as petroleum refining processes, primary metals manufacturing and chemical industries consume more energy in comparison with textile or agriculture industries (Jones, 1991; Samouilidis and Mitropoulos, 1984). As the consumption of energy will be more compare to traditional agriculture, the shift towards industrialization has been shown increases in energy intensity (Sadorsky, 2013; Shahbaz \& Lean 2012). Bernardini and Galli (1993) state that energy intensity increases when an economy expands during the industrialization stage since the consumption of energy increases to support the need for construction of infrastructures. Technological progress will be brought by economic growth in the next stage to enhance energy efficiency. Pan, Uddin, Saima, Jiao, and Han (2019) showed that industrialization has a direct positive impact on energy intensity. In addition, Belloumi and Alshehry (2016) and Guang, He, Wen, and Sharp (2019) showed that industrialization and urbanization have positive and significant impacts on energy intensity. Adom and Amuakwa-Mensah (2016) concluded that intense industrialization and FDI lower energy productivity in low income countries.

\subsection{Institutional Quality}

Since the works of Coase (1937; 1991), North (1994), Nelson and Winter (1985) and Williamson (2009) to explain technical change and economic growth, institutions have become increasingly important in understanding economic behavior. Nelson and Winter (1985) provide significant evidence to show that institutional change has been the key driver of economic growth and structural change. Hence, a myriad of institutions should be considered as key influences in transforming the conduct of socioeconomic agents to lower energy intensity in the use of fuels in production, distribution and consumption. Institutions received a further boost following the quantitative work of Acemoglu, Johnson, and Robinson (2005) and Acemoglu and Robinson (2012), albeit their understanding of institutions appears somewhat simplistic (see Zhang \& Rasiah, 2015).

According to North (1990), institutions refer to the rules of the game defined by economic, social and political interactions, while firms and organizations are the players conditioned by those rules. This definition indicates that institutional framework comprises all types of socially derived influences, including formal and informal that determine human interactions, including economic exchange. The effective protection of property and civil rights, higher levels of political and economic freedom and lower corruption levels were found to be associated with higher prosperity (Bénassy-Quéré et al., 2007).

Several empirical studies confirm the influence of institutions in attracting FDI to spur economic growth and structural change. In addition to natural endowments, host-country governments offer a wide range of incentives to attract FDI (Hirschman, 1970; Rasiah, 1995; Ali, Fiess \& MacDonald (2010); Azam, 2010; Daude \& Stein, 2007). Recent reports show institutional conditioning is important to maximize economic gains from FDI. For instance, Buchanan, Le, and Rishi (2012) argued that institutional quality has been the main reason why Russia received US\$3 billion per month less than China. 
A number of studies also show that political institutions affect FDI inflows and economic growth in host-countries (Stevens, 1969; Levis, 1979; Schneider \& Frey, 1985; Wei, 1997; Asiedu, 2006; Asiedu \& Villamil, 2000; Aw \& Tang, 2010). Dunning (1993) and Daude and Stein (2007) argued that poor institutional quality raises transactions costs and uncertainty, which is confirmed by Daniels, Radebaugh, and Sullivan (2002); Biswas, 2002; Imad, 2002 and Li, 2008.

Technology diffusion has an essential role in the economic development process. In comparison with the traditional growth theory, which left the technological changes as an unexplained residual, recent growth theories include the level of domestic technology in modeling the economic growth (Borensztein et al., 1998). One of the main sources of technological diffusion process is FDI which can facilitate technological changes through knowledge spillover and new capital goods (Hermes \& Lensink, 2003) and studies confirmed that the FDI flow is significantly affected by institutional quality (Peres, Ameer, \& Xu (2018); Bouchoucha \& Benammou, 2018). Higher level of technology results in more efficient energy use and hence lowers energy intensity which led the inclusion of institutional quality in modeling energy intensity.

As a result, we test the variables of energy prices, trade, FDI, urbanization, industrialization, and institutions as explanatory variables against the dependent variable of energy intensity. Institutional quality is the new variable we include in the paper.

\section{METHODOLOGY AND DATA}

In the first part of this section we present an empirical model for testing the relationships between the explanatory and dependent variables, data sources and measurement of the variables.

The empirical model of this study is a dynamic panel estimate of energy intensity. Energy intensity (EI) is formulated as a function of energy price (EP), trade (TRADE), urbanization (UR), Foreign Direct Investment (FDI), Industrialization (IND), and Institutional Quality (IQ). However, given the problems of measuring institutional quality, we use political risk (PR) to capture institutional quality:

$$
e i_{i t}=\alpha e i_{i t-1}+\beta_{1} e p_{i t}+\beta_{2} \text { trade }_{i t}+\beta_{3} u r_{i t}+\beta_{4} f d i_{i t}+\beta_{5} i n d_{i t}+\beta_{6} p r_{i t}+\varepsilon_{i t}
$$

In this equation the subscript $i(i=1, \ldots, 84)$ refers to countries, while the subscript $t$ denotes the year $(t=1980, \ldots, 2012)$. This equation allows for dynamic effects by considering the lag of the dependent variable.

In this equation the dependent variable is energy intensity, which is measured by the ratio of energy consumption in $\mathrm{KTOE}^{4}$ to GDP at constant 2005 US dollar prices. The independent variables were measured as follows:

$\mathrm{EP}=$ nominal Brent crude oil prices deflated with consumer price index (CPI) $(2010=100)$ $\mathrm{FDI}=$ net FDI inflows $(\%$ of GDP)

TRADE $=$ sum of imports and exports of goods and services (\% of GDP)

\footnotetext{
${ }^{4}$ kilo ton of oil equivalent
} 
$\mathrm{UR}=$ population who live in the urban areas (in \%)

$\mathrm{IND}=$ industrial value added $(\%$ of GDP)

PR = ICRG Index of Political Risk

Fragile States Index is used for the purpose of classification of countries.

All variables were converted to natural logarithms to capture elasticities (Komal \& Abbas, 2015). Data on PR was collected from the International Country Risk Guide (ICRG). This dataset is prepared by the Political Risk Services (PRS) Group. The political risk index of ICRG is a composite score ranging from zero to 100 denoting Low Risk (0-49.9 points) to very high risk (80100 points). PR was estimated using 12 variables (weighted), which cover both social and political features of the countries. The ICRG index is a composite socio-political index which is more representative than individual variable indices since disaggregate indices may include measurement errors which can result in estimation problems (Kolstad \& Villanger, 2008). The index components address not only political risk but also different components of political institutions which includes: Government Stability (12 points) evaluates ability of particular governments to accomplish its declared programs, as well as its strength to settle in office. Socioeconomic conditions (12 points) evaluates the socioeconomic pressures at work in the country that can cause restriction in government actions and reinforce dissatisfaction in the society. Poverty and Unemployment can increase socioeconomic pressure and social dissatisfaction. Investment Profile (12 points), which measures the significant factors that affect the risk to investment and were not considered by other economic, political or financial risk elements. Internal Conflict (12 points) assesses political cruelty in the country and its potential or actual effects on governance. External Conflict (12 points) evaluates the risk of foreign action for the incumbent government which could be non-violent or violent external pressure. Corruption (6 points) evaluates corruption within a political system. Corruption is a barrier to foreign investment as it causes distortion in financial and economic environment. Businesses commonly face financial corruption directly which includes demanding for bribes related to loans, tax assessments, trading licenses, exchange controls or police protection. Financial corruption causes ineffective businesses operation, and it may lead to termination or abolition of an investment. Military in Politics (6 points) demonstrates the effects of the military in politics. As there is no election for military, its political intervention results in democratic accountability reduction. Religious Tensions (6 points) measures religious tensions which happens when a religious group dominates society or governance and tries to substitute civil laws by religious laws or attempts to deprive other religions from the social and political processes. Law and Order (6 points) evaluates the impartiality and strength of a legal system. Ethnic Tensions (6 points) evaluates the tension degrees among ethnic groups such as different races, nationality or languages. Democratic Accountability (6 points) measures the responsiveness of a government to its nation. The lower responsiveness of the government will increase the possibility that the government will fall. Although the major government falls happen peacefully in democratic societies, it might happen with violence in a non-democratic one. Bureaucracy Quality (4 points) represents the institutional quality and strength of the bureaucracy. Bureaucracy Quality might behave as a shock absorber in order to decrease policy reviews if a governments changes.

We included the Fragile States Index (FSI) to differentiate countries using twelve primary economic, political and social indicators. The social indicators consist of human flight and brain drain, group grievance, demographic pressures and refugees and internally displaced persons. 
Economic Indicators of FSI consist of level of poverty and economic development. Political and military indicators comprise human rights, state legitimacy, public services and rule of law, security apparatus, factionalized elites and external intervention. Each indicator ranges from 0 to 10 , with 0 being the most stable and 10 being the least stable. The cumulative FSI consequently ranges from 0 to 120 (Table 1). For the purpose of this study, the panel of countries were divided into two groups: countries with scores below 60 and countries above 60 . Hence, the two groups represent stable and unstable countries.

Table 1: FSI Country Categorization

\begin{tabular}{cc}
\hline \hline Category & FSI Score \\
\hline Very High Alert & $110-120$ \\
High Alert & $100-110$ \\
Alert & $90-100$ \\
High Warning & $80-90$ \\
Elevated Warning & $70-80$ \\
Warning & $60-70$ \\
Stable & $50-60$ \\
More Stable & $40-50$ \\
Very Stable & $30-40$ \\
Sustainable & $20-30$ \\
Very Sustainable & $0-20$ \\
\hline \hline
\end{tabular}

Source: Fund for Peace

The statistical relationships in the equation above were analyzed using Dynamic Panel Generalized Method of Moments (GMM). As countries represent different characteristics in terms of nature and structure, it is realistic to assume that they are not homogenous. Therefore, to overcome this problem and have more accurate estimations, panel data analysis is used. GMM is an estimator that was proposed by Arellano and Bond (1991) and Arellano (1993) for single and systems equations (Arellano, 1993; Arellano \& Bond, 1991). It is a robust estimator, which does not need information regarding accurate distribution of error terms (Komal \& Abbas, 2015).

The GMM estimation method is generally used in dynamic models deploying panel data with a lagged dependent variable. Using a set of instrumental variables this technique can solve endogeneity problems of regressors (Omri \& Kahouli, 2014). This estimation technique uses instrumental variables to generate consistent and unbiased estimation of parameters. Even if the instrumental variables are correlated with the independent variables in the equation, they will be uncorrelated with disturbances. The instrumental variables are able to eliminate correlations between independent variables and disturbances. As a result, estimates provided by GMM are consistent and reliable (Komal \& Abbas, 2015).

The Arellano-Bond estimation technique transforms all regressors via differencing, and application of GMM (Roodman, 2006). Difference GMM has some drawbacks, since it has a poor behavior in persistent time series. The reason is that the lagged level of the variables that are used as weak instruments for subsequent first difference are still correlated with disturbances. Hence, Arellano and Bover (1995) and Blundell and Bond (1998) developed an estimator called system GMM in order to solve this problem. Roodman (2006) states that the Arellano-Bover/BlundellBond estimator, by considering an extra assumption that the first differences of instrumental 
variables are uncorrelated with the fixed effects, augments Arellano-Bond. This will allow introducing higher number of instruments and substantially ameliorate efficiency. It creates a system including two equations, the transformed and the original equation, which is named system GMM (Roodman, 2006). Hence, application of system GMM helps to obtain unbiased estimates by solving the problem of omitted variables and there will be no problem of endogeneity as well. Moreover, taking first differences helps to solve the problem of the country specific effect.

Both system GMM and difference GMM are general estimators suitable for conditions with small time periods and large observations panels. They are also appropriate for linear functional relationships with a dependent variable which is dynamic and depends on its own past trends and independent variables which are not purely exogenous, meaning they are correlated with past and perhaps current series of the errors; fixed effects; and heteroscedasticity and autocorrelation among observations (Roodman, 2006).

The study deployed secondary data from annual macro-level panel data collected for the period 1980 to 2012 on 84 countries. The sources of data are as follows: World Bank for CPI, energy use, FDI, GDP, crude oil price and trade openness data. British Petroleum, the Political Risk Group for institutional quality, and FSI from the Fund for Peace.

\section{RESULTS AND DISCUSSION}

Tables 2, 3 and 4 present the results of the relationship between EP, Trade, FDI, UR, IND, and PR, using two-step system GMM. Diagnostic checks for autocorrelation and over-identifying restrictions were performed. The results showed first order serial correlation as p-value is less than 0.05 , but the null hypothesis for the second order serial correlation is clear ( $p$-value $>0.05$ ). The results are also validated in all three regressions as the Hansen test statistics has a p-value greater than 0.10 . The coefficients of all the independent variables have the right signs in the overall global panel (Table 2). However, EP and UR were not significant. Increasing trade openness and industrialization raises energy intensity, while increasing FDI and PR lowers energy intensity. A $1 \%$ increase in FDI will reduce energy intensity by $0.004 \%$ among the global panel of countries. Whereas the former suggests that energy raising economic activity expands with trade and industrialization, the latter shows that growth in FDI and improvements in institutional quality lowers energy intensity. A $1 \%$ increase in industrialization will lead to $0.02 \%$ increase in energy intensity among the global panel of countries. A $1 \%$ increase in institutional quality in the global panel will lead to $0.02 \%$ decrease in energy intensity. 
Table 2: Determinants of Energy Intensity, Global Panel Data, 1980-2012

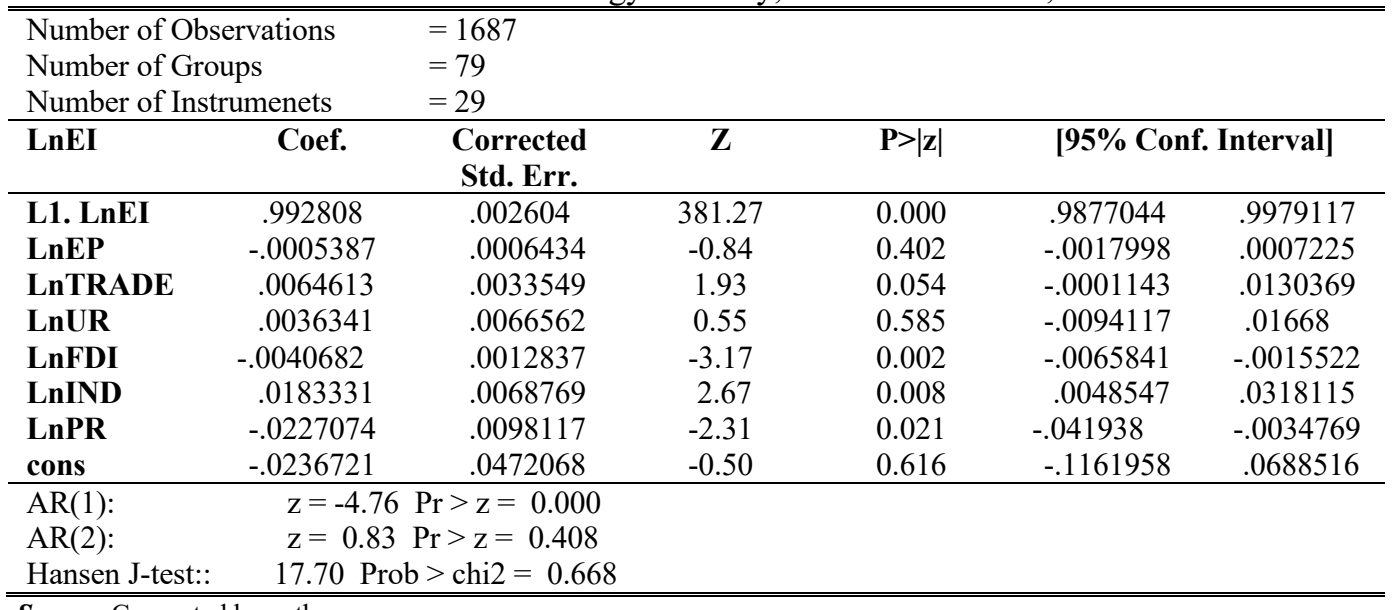

Source: Computed by authors

The coefficients also show the right signs among stable countries (Table 3). However, EP was significant demonstrating the importance of energy prices in reducing energy intensity. TRADE, UR and IND were not significant suggesting that the stable countries are more mature with little changes in trade and industrialization affecting energy intensity. FDI and PR show an inverse relationship with energy intensity. The former showing improvements in energy efficiency, while the latter demonstrating the important role of institutional quality on lowering energy intensity. A $1 \%$ increase in FDI will result in $0.005 \%$ reduction in energy intensity among stable countries. A $1 \%$ improvement in PR will result in $0.06 \%$ decrease in energy intensity in stable countries.

Table 3: Determinants of Energy Intensity, Stable Countries, 1980-2012

\begin{tabular}{|c|c|c|c|c|c|c|}
\hline \multicolumn{3}{|c|}{$\begin{array}{l}\text { Number of Observations } \\
\text { Number of Groups } \\
\text { Number of Instruments }\end{array}$} & \multicolumn{4}{|l|}{$\begin{array}{l}=35 \\
=29\end{array}$} \\
\hline LnEI & Coef. & Corrected Std. Err. & $\mathbf{Z}$ & $\mathbf{P}>|\mathbf{z}|$ & \multicolumn{2}{|c|}{ [95\% Conf. Interval] } \\
\hline L1. LnEI & .9916133 & .0065051 & 152.44 & 0.000 & .9788637 & 1.004363 \\
\hline LnEP & -.0044044 & .0018944 & -2.32 & 0.020 & -.0081174 & -.0006914 \\
\hline LnTRADE & .0056844 & .0042648 & 1.33 & 0.183 & -.0026744 & .0140433 \\
\hline LnUR & -.0082241 & .0067711 & -1.21 & 0.225 & -.0214953 & .0050471 \\
\hline LnFDI & -.0046308 & .0019285 & -2.40 & 0.016 & -.0084107 & -.000851 \\
\hline LnIND & .0237309 & .0159745 & 1.49 & 0.137 & -.0075786 & .0550403 \\
\hline LnPR & -.0558354 & .031163 & -1.79 & 0.073 & -.1169138 & .005243 \\
\hline cons & .1519256 & .1363394 & 1.11 & 0.265 & -.1152947 & .4191459 \\
\hline $\mathrm{AR}(1):$ & \multicolumn{6}{|c|}{$\mathrm{z}=-2.65 \operatorname{Pr}>\mathrm{z}=0.008$} \\
\hline $\operatorname{AR}(2)$ & \multicolumn{6}{|c|}{$z=0.65 \operatorname{Pr}>z=0.519$} \\
\hline Hansen J-test: & \multicolumn{6}{|c|}{ 25.18 $\operatorname{Prob}>$ chi $2=0.239$} \\
\hline
\end{tabular}

Source: Computed by authors

Finally, the coefficients also show the right signs among unstable countries (Table 4). However, only FDI and PR were significant. Whereas FDI is highly significant (at 1\%), PR is only significant at the $10 \%$ level. The results suggest that FDI brings with it energy-saving technologies, while the 
latter suggest that institutional weaknesses have lowered the statistical significance of PR in unstable countries. A $1 \%$ increase in FDI will generate a $0.004 \%$ reduction in energy intensity among unstable countries. A $1 \%$ improvement in PR will result in $0.03 \%$ reduction in energy intensity among unstable countries. Higher level of institutional quality means less political risk

Table 4: Determinants of Institutional Quality, Unstable Countries, 1980-2012

\begin{tabular}{|c|c|c|c|c|c|c|}
\hline \multicolumn{3}{|c|}{$\begin{array}{l}\text { Number of Observations } \\
\text { Number of Groups } \\
\text { Number of Instruments }\end{array}$} & $\begin{array}{l}=1023 \\
=45 \\
=29\end{array}$ & & & \\
\hline LnEI & Coef. & Corrected Std. Err. & $\mathbf{z}$ & $\mathbf{P}>|\mathbf{z}|$ & \multicolumn{2}{|c|}{ [95\% Conf. Interval] } \\
\hline L1. LnEI & .9909347 & .0045846 & 216.14 & 0.000 & .981949 & .9999204 \\
\hline LnEP & -.0004629 & .0007759 & -0.60 & 0.551 & -.0019836 & .0010579 \\
\hline LnTRADE & .0065116 & .0043284 & 1.50 & 0.132 & -.0019719 & .0149951 \\
\hline LnUR & .0051043 & .009675 & 0.53 & 0.598 & -.0138585 & .024067 \\
\hline LnFDI & -.0036537 & .0014246 & -2.56 & 0.010 & -.0064459 & -.0008616 \\
\hline LnIND & .0081965 & .0086762 & 0.94 & 0.345 & -.0088086 & .0252016 \\
\hline LnPR & -.0263942 & .0155192 & -1.70 & 0.089 & -.0568113 & .004023 \\
\hline cons & .0194442 & .0660641 & 0.29 & 0.769 & -.110039 & .1489274 \\
\hline $\mathrm{AR}(1):$ & \multicolumn{6}{|c|}{$\mathrm{z}=-4.35 \operatorname{Pr}>\mathrm{z}=0.000$} \\
\hline $\operatorname{AR}(2)$ & \multicolumn{6}{|c|}{$\mathrm{z}=0.59 \operatorname{Pr}>\mathrm{z}=0.552$} \\
\hline Hansen J-test: & \multicolumn{6}{|c|}{ 22.93 Prob $>$ chi $2=0.348$} \\
\hline
\end{tabular}

Source: Computed by authors

Taken together, FDI appears to have highly significant contribution in lowering energy intensity as its coefficient is negative and highly significant (at 1\%) in all three groups of countries, which are consistent with the findings of Bento (2011), Eskeland and Harrison (2003), Mielnik and Goldemberg (2002) and Sbia et al., (2014). The same can be said of institutional quality as the lowering of PR reduces energy intensity in all three groups of countries. Increasing industrialization raises energy intensity in the global panel and stable countries suggesting that stability is a critical factor in the promotion of industrialization. Whereas Sadorsky (2013), Salim and Shafiei (2014), and Shahbaz and Lean (2012) found industrialization to exacerbate energy intensity, our results show that such a relationship is not significant among unstable countries. Trade showed a significant relationship only in the global panel of countries, and its growth raises energy intensity. The positive link between trade openness and energy intensity is consistent with the findings of Hübler (2009) and Nasreen and Anwar (2014). Urbanization had no relationship with energy intensity among all three groups of countries which is inconsistent with the findings of Jones, (1991), Komal and Abbas, (2015), Mishra et al., (2009), Sadorsky, (2013), Salim and Shafiei, (2014) and Shahbaz and Lean, (2012) who found urbanization to significantly affect energy demand. Energy prices represented a significant coefficient only in group of stable countries meaning that using instruments such as taxes or subsidies to influence energy prices is an effective policy tool in stable countries. The sign of this coefficient is negative and consistent with a downward sloping demand for energy equation where energy prices are approximated by oil prices. This is in line with the work of Hang and Tu (2007), Yan (2015) and Wu (2012) who found that increasing energy prices is an applicable policy for improving energy use efficiency. 


\section{CONCLUSIONS}

The results of this exercise only confirm some of the arguments advanced by previous authors. FDI in particular showed a highly significant contribution towards lowering energy intensity as its coefficients were negative and highly significant (at 1\%) in all three groups of countries. Whereas urbanization had no impact on energy-intensity levels in all three groups of countries, industrialization and trade exacerbated energy intensity in the global panel of countries. Industrialization worsened energy intensity among stable countries. The new variable of institutional quality had a significant and positive impact on reducing energy intensity in all three groups of countries.

Since the extant literature also shows that institutional quality positively stimulates FDI inflows, it can be concluded that policies should focus on improving institutional quality to stimulate both a reduction in energy intensity and to stimulate FDI inflows. More specifically, stable and responsive government, impartial legal system, better bureaucracy quality, less internal and external conflicts, lower unemployment and poverty, lower investment risks, lower corruption, less military intervention in politics, less religious tensions and ethnic tensions are the policies which can improve institutional quality. Future studies should test the mediating effect of institutional quality on the relationship between trade, FDI, industrialization and urbanization, and energy intensity using structural equation modelling to introduce IQ as a mediator. In doing so more and more effective proxies should be used to test the individual, as well as collective impact of institutional variables on energy intensity.

\section{REFERENCES}

Acemoglu, D., Johnson, S., \& Robinson, J.A. (2005). Institutions as a fundamental cause of longrun growth: Handbook of economic growth. Netherlands: Elsevier B. V.

Acemoglu, D., \& Robinson, J.A. (2012). Why Nations Fail. The Origin of Power, Prosperity and Poverty. New York: Crown Publisher.

Adom, P. K., \& Amuakwa-Mensah, F. (2016). What drives the energy saving role of FDI and industrialization in East Africa?. Renewable and Sustainable Energy Reviews, 65, 925942.

Adom, P. K. (2015). Asymmetric impacts of the determinants of energy intensity in Nigeria. Energy Economics, 49, 570-580.

Adom, P. K., \& Kwakwa, P. A. (2014). Effects of changing trade structure and technical characteristics of the manufacturing sector on energy intensity in Ghana. Renewable and Sustainable Energy Reviews, 35, 475-483.

Alam, A., Malik, I. A., Abdullah, A. B., Hassan, A., Awan, U., Ali, G., Zaman, K., \& Naseem, I. (2015). Does financial development contribute to SAARC' S energy demand? From energy crisis to energy reforms. Renewable and Sustainable Energy Reviews, 41, 818-829.

Alcala F., \& Ciccone, A. (2004). Trade and productivity. Quarterly Journal of Economics, 119(2), 612-645.

Alcantara, V., \& Duarte, R. (2004). Comparison of energy intensities in European Union countries. Results of a structural decomposition analysis. Energy policy, 32(2), 177-189.

Alfaro, L., Chanda, A., Kalemli-Ozcan, S., \& Sayek, S. (2004). FDI and economic growth: the role of local financial markets. Journal of international economics, 64(1), 89-112. 
Alfaro, L., Chanda, A., Kalemli-Ozcan, S., \& Sayek, S. (2006). How does foreign direct investment promote economic growth? Exploring the effects of financial markets on linkages. NBER Working Paper No. 12522. Cambridge, Ma: National Bureau of Economic Research.

Alfaro, L., Kalemli-Ozcan, S., \& Volosovych, V. (2008). Why doesn't capital flow from rich to poor countries? An empirical investigation. The Review of Economics and Statistics, 90(2), 347-368.

Alguacil, M., Cuadros, A., \& Orts, V. (2011). Inward FDI and growth: The role of macroeconomic and institutional environment. Journal of Policy Modeling, 33(3), 481-496.

Ali, F. A., Fiess, N., \& MacDonald, R. (2010). Do institutions matter for foreign direct investment? Open Economies Review, 21(2), 201-219.

Ang, B. W., \& Zhang, F. (2000). A survey of index decomposition analysis in energy and environmental studies. Energy, 25(12), 1149-1176.

Antweiler, W., Copeland, B.R., \& Taylor, M.S. (2001). Is free trade good for the environment? American Economic Review, 91(4), 877-908.

Arellano, M. (1993). On the testing of correlated effects with panel data. Journal of Econometrics, 59(1-2), 87-97.

Arellano, M., \& Bond, S. (1991). Some tests of specification for panel data: Monte Carlo evidence and an application to employment equations. The review of economic studies 58(2), 277297.

Arellano, M., \& Bover, O. (1995). Another look at the instrumental variable estimation of errorcomponents models. Journal of Econometrics, 68(1), 29-51.

Asiedu, E. (2006). Foreign direct investment in Africa: The role of natural resources, market size, government policy, institutions and political instability. The World Economy, 29(1), 6377.

Asiedu, E., \& Villamil, A. P. (2000). Discount factors and thresholds: Foreign investment when enforcement is imperfect. Macroeconomic Dynamics, 4(1), 1-21.

Aw, Y. T, \& Tang, T. C. (2010). The determinants of inward foreign direct investment: The case of Malaysia. International Journal of Business and Society, 11(1), 59-76.

Azam, M. (2010). An empirical analysis of the impacts of exports and foreign direct investment on economic growth in South Asia. Interdisciplinary Journal of Contemporary Research in Business, 2(7), 249-258.

Bailliu, J.N. (2000). Private capital flows, financial development, and economic growth in developing countries. Bank of Canada Working Paper (2000-15). Ottawa: International Department Bank of Canada.

Baležentis, A., Baležentis, T., \& Streimikiene, D. (2011). The energy intensity in Lithuania during 1995-2009: a LMDI approach. Energy Policy, 39(11), 7322-7334.

Belloumi, M., \& Alshehry, A. S. (2016). The impact of urbanization on energy intensity in Saudi Arabia. Sustainability, 8(4), 375.

Bernardini, O., \& Galli, R. (1993). Dematerialization: long-term trends in the intensity of use of materials and energy. Futures, 25(4), 431-448.

Bénassy-Quéré, A., Coupet, M., \& Mayer, T. (2007). Institutional determinants of foreign direct investment. The World Economy, 30(5), 764-782.

Bento, J.P. (2011). Energy savings via foreign direct investment?-Empirical evidence from Portugal. Working Paper No. 2011/24. Netherlands: Maastricht School of Management

Birol, F., \& Keppler, J.H. (2000). Prices, technology development and the rebound effect. Energy policy, 28(6-7), 457-469. 
Biswas, R. (2002). Determinants of foreign direct investment. Review of development economics, $6(3), 492-504$.

Blalock, G., \& Gertler, P. J. (2008). Welfare gains from foreign direct investment through technology transfer to local suppliers. Journal of International Economics, 74(2), 402-421.

Blundell, R., \& Bond, S. (1998). Initial conditions and moment restrictions in dynamic panel data models. Journal of Econometrics, 87, 115-143.

Borensztein, E., De Gregorio, J., \& Lee, J. W. (1998). How does foreign direct investment affect economic growth? Journal of international Economics, 45, 115-135.

Bouchoucha, N., \& Benammou, S. (2018). Does institutional quality matter foreign direct investment? Evidence from African countries. Journal of the Knowledge Economy, 11, 390-404.

British Petroleum Statistical Review of World Energy (2014). Retrieved from http://arge.stanford.edu/courses/2014/ph240/milic1/docs/bpreview.pdf

Buchanan, B.G., Le, Q.V., \& Rishi, M. (2012). Foreign direct investment and institutional quality: Some empirical evidence. International Review of Financial Analysis, 21, 81-89.

Busse, M., \& Hefeker, C. (2007). Political risk, institutions and foreign direct investment. European journal of political economy, 23(2), 397-415.

Butler, K. C., \& Joaquin, D. C. (1998). A note on political risk and the required return on foreign direct investment. Journal of International Business Studies, 29, 599-607.

Caves, R. E. (1974). Multinational firms, competition, and productivity in host-country markets. Economica, 41(162), 176-193.

Chang, S. C. (2015). Effects of financial developments and income on energy consumption. International Review of Economics \& Finance, 35, 28-44.

Chen, H., Jia, B., \& Lau, S. (2008). Sustainable urban form for Chinese compact cities: Challenges of a rapid urbanized economy. Habitat International, 32(1), 28-40.

Chen, S., \& Chen, B. (2015). Urban energy consumption: different insights from energy flow analysis, input-output analysis and ecological network analysis. Applied Energy, 138, 99107.

Coase, R. H. (1937). The nature of the firm. Economica, 4(16), 386-405.

Coase, R. H. (1991). Biography of Ronald H. Coase. Nobel Prize Ceremony. Retrieved from https://www.nobelprize.org/prizes/economic-sciences/1991/coase/biographical/

Cole, M. A. (2006). Does trade liberalization increase national energy use? Economics Letters, 92(1), 108-112.

Cornillie, J., \& Fankhauser, S. (2004). The energy intensity of transition countries. Energy Economics, 26(3), 283-295.

Daniels, J. D., Radebaugh, L. H., \& Sullivan, D. P. (2002). Globalization and business. New Jersey, US: Prentice Hall.

Daude, C., \& Stein, E. (2007). The quality of institutions and foreign direct investment. Economics \& Politics, 19(3), 317-344.

Dunning, J. (1993). Multinational Enterprises and the Global Economy. Boston, US: AddisonWesley Publishing Company Inc.

Edmonson, N. (1975). Real price and the consumption of mineral energy in the United States, 1901-1968. The Journal of Industrial Economics, 23(3), 161-174.

Eichengreen, B. J. (2004). Capital flows and crises. Cambridge, US: MIT press.

Eskeland, G.S., \& Harrison, A.E. (2003). Moving to greener pastures? Multinationals and the pollution haven hypothesis. Journal of development economics, 70(1), 1-23. 
Goldemberg, J., \& Prado, L.T.S. (2011). The decline of the world's energy intensity. Energy Policy, 39(3), 1802-1805.

Guang, F., He, Y., Wen, L., \& Sharp, B. (2019). Energy intensity and its differences across China's regions: Combining econometric and decomposition analysis. Energy, 180, 989-1000.

Hang, L., \& Tu, M. (2007). The impacts of energy prices on energy intensity: Evidence from China. Energy policy, 35(5), 2978-2988.

Hermes, N., \& Lensink, R. (2003). Foreign direct investment, financial development and economic growth. The Journal of Development Studies, 40(1), 142-163.

Hirschman, A. O. (1970). Exit, voice, and loyalty: Responses to decline in firms, organizations, and states. Cambridge, US: Harvard University Press.

Hübler, M. (2009). Energy saving technology diffusion via FDI and trade: a CGE model of China. Kiel Working Paper No. 1479. Kiel Institute for the World Economy.

Imad, M. (2002). FDI Theory, Evidence and Practice. Chippenham, Wiltshire, UK: Antony Rowe. International Monetary Fund (IMF). (2003). World economic outlook. Retrieved from https://www.imf.org/en/Publications/SPROLLs/world-economic-outlookdatabases\#sort $=\%$ 40imfdate $\% 20$ descending

Jones, D. W. (1991). How urbanization affects energy-use in developing countries. Energy Policy, 19(7), 621-630.

Jude, C., \& Levieuge, G. (2017). Growth Effect of Foreign Direct Investment in Developing Economies: The Role of Institutional Quality. The World Economy, 40(4), 715-742.

Kim, S.T. (1989). Aggregate energy demand in OECD counties: Methodological and empirical investigations. Texas A\&M University, College Station, Texas.

Kolstad, I., \& Villanger, E. (2008). Determinants of foreign direct investment in services. European Journal of Political Economy, 24(2), 518-533.

Komal, R., \& Abbas, F. (2015). Linking financial development, economic growth and energy consumption in Pakistan. Renewable and Sustainable Energy Reviews, 44, 211-220.

Lee, J. W. (2013). The contribution of foreign direct investment to clean energy use, carbon emissions and economic growth. Energy Policy, 55, 483-489.

Levis, M. (1979). Does political instability in developing countries affect foreign investment flow? An empirical examination. Management International Review, 19, 59-68.

Li, Q. (2008). Foreign direct investment and interstate military conflict. Journal of International Affairs, 62(1), 53-66.

Liddle, B. (2004). Demographic dynamics and per capita environmental impact: Using panel regressions and household decompositions to examine population and transport. Population and Environment, 26, 23-39.

Lucas, R.E. (1990). Why doesn't capital flow from rich to poor countries? The American Economic Review, 80(2), 92-96.

Mielnik, O., Goldemberg, J. (2002). Foreign direct investment and decoupling between energy and gross domestic product in developing countries. Energy policy, 30(2), 87-89.

Mishra, V., Smyth, R., \& Sharma, S. (2009). The energy-GDP nexus: evidence from a panel of Pacific Island countries. Resource and Energy Economics, 31(3), 210-220.

Nasreen, S., \& Anwar, S. (2014). Causal relationship between trade openness, economic growth and energy consumption: A panel data analysis of Asian countries. Energy Policy, 69, 8291.

Nelson, R. R. \& Winter, S.G. (1985). An evolutionary theory of economic change. Cambridge, US: Harvard University Press. 
North, D.C. (1990). Institutions, Institutional Change and Economic Performance. New York, US: Cambridge University Press.

North, D.C. (1994). Economic performance through time. The American economic review, 84(3), 359-368.

Omri, A., \& Kahouli, B. (2014). Causal relationships between energy consumption, foreign direct investment and economic growth: Fresh evidence from dynamic simultaneous-equations models. Energy Policy, 67, 913-922.

Pariakh, J., \& Shukla, V. (1995). Urbanization, energy use and greenhouse effects in economic development. Global Environmental Change, 5, 87-103.

Pan, X., Uddin, M. K., Saima, U., Jiao, Z., \& Han, C. (2019). How do industrialization and trade openness influence energy intensity? Evidence from a path model in case of Bangladesh. Energy Policy, 133, 110916.

Peres, M., Ameer, W., \& Xu, H. (2018). The impact of institutional quality on foreign direct investment inflows: evidence for developed and developing countries. Economic researchEkonomska istraživanja, 31(1), 626-644.

Poumanyvong, P., \& Kaneko, S. (2010). Does urbanization lead to less energy use and lower CO 2 emissions? A cross-country analysis. Ecological Economics, 70(2), 434-444.

Rafiq, S., Salim, R., \& Nielsen, I. (2016). Urbanization, openness, emissions, and energy intensity: a study of increasingly urbanized emerging economies. Energy Economics, 56, 20-28.

Rasiah, R. (1995). Foreign Capital and Industrialization in Malaysia. Basingstoke: Macmillan.

Rasiah, R., Al-Amin, A.Q., Ahmed, A., Filho, W.L. \& Calvo, E. (2016) "Climate mitigation roadmap: assessing low carbon scenarios for Malaysia”, Journal of Cleaner Production, 133(10), 272-283.

Reinhart, C. M., \& Rogoff, K. S. (2004). Serial default and the" paradox" of rich-to-poor capital flows. American Economic Review, 94, 53-58.

Roodman, D. (2006). How to do xtabond2: An introduction to difference and system GMM in Stata. Center for Global Development Working Paper No. 103. Center for Global Development

Sadorsky, P. (2011). Trade and energy consumption in the Middle East. Energy Economics, 33(5), 739-749.

Sadorsky, P. (2012). Energy consumption, output and trade in South America. Energy Economics, 34(2), 476-488.

Sadorsky, P. (2013). Do urbanization and industrialization affect energy intensity in developing countries? Energy Economics, 37, 52-59.

Salim, R.A., \& Shafiei, S. (2014). Urbanization and renewable and non-renewable energy consumption in OECD countries: An empirical analysis. Economic Modelling, 38, 581591.

Samouilidis, J.-E., \& Mitropoulos, C. (1984). Energy and economic growth in industrializing countries: the case of Greece. Energy Economics, 6(3), 191-201.

Sbia, R., Shahbaz, M., \& Hamdi, H. (2014). A contribution of foreign direct investment, clean energy, trade openness, carbon emissions and economic growth to energy demand in UAE. Economic Modelling, 36, 191-197.

Schneider, F., \& Frey, B. S. (1985). Economic and political determinants of foreign direct investment. World development, 13(2), 161-175.

Shahbaz, M., \& Lean, H. H. (2012). Does financial development increase energy consumption? The role of industrialization and urbanization in Tunisia. Energy policy, 40, 473-479. 
Shahbaz, M., Nasreen, S., Ling, C.H., \& Sbia, R. (2014). Causality between trade openness and energy consumption: What causes what in high, middle and low income countries. Energy policy, 70, 126-143.

Shen, L. (2007). The changes of China's foreign trade structure is harmful to energy-saving and consumption-reducing. Management World, 10, 43-50.

Shi, A. (2003). The impact of population pressure on global carbon dioxide emissions, 1975-1996: evidence from pooled cross-country data. Ecological Economics, 44(1), 29-42.

Solarin, S. A., \& Shahbaz, M. (2013). Trivariate causality between economic growth, urbanisation and electricity consumption in Angola: Cointegration and causality analysis. Energy Policy, 60, 876-884.

Stevens, G. V. (1969). US direct manufacturing investment to Latin America: Some economic and political determinants, AID Research Pape.

Stern, N. (2007). The Stern Report: The truth about climate change, Spain: Editorial Paidós.

Sun, J. (2002). The decrease in the difference of energy intensities between OECD countries from 1971 to 1998. Energy Policy, 30, 631-635.

United Nations. (1997). Conference of the Parties, Third Session, Kyoto Protocol to the United Nations Framework Convention on Climate Change, Kyoto, Japan. Retrieved from https://unfccc.int/resource/docs/convkp/kpeng.pdf

Waugh, M. E. (2010). International trade and income differences. American Economic Review, 100(5), 2093-2124.

Wei, S. J. (1997). Why is corruption so much more taxing than tax? Arbitrariness kills. National Bureau of Economic Research.

Williamson, C. R. (2009). Informal institutions rule: institutional arrangements and economic performance. Public Choice, 139(3-4), 371-387.

World Bank. (2016). World Bank Open Data. Retrieved from https://data.worldbank.org/

$\mathrm{Wu}, \mathrm{Y}$. (2012). Energy intensity and its determinants in China's regional economies. Energy Policy, 41, 703-711.

Wu, J., Wu, Y., Cheong, T. S., \& Yu, Y. (2018). Distribution dynamics of energy intensity in Chinese cities. Applied Energy, 211, 875-889.

Yan, H. (2015). Provincial energy intensity in China: The role of urbanization. Energy Policy, 86, 635-650.

Zaman, K., Khan, M.M., Ahmad, M., \& Rustam, R. (2012). Determinants of electricity consumption function in Pakistan: Old wine in a new bottle. Energy Policy, 50, 623-634.

Zhang, M., \& Rasiah, R. (2015) Institutionalization of State Policy: Evolving Urban Housing Reforms in China, New York: Springer. 